\title{
The Role of Food Standards in International Trade: Assessing the Brazilian Beef Chain
}

\author{
Luciana Marques Vieira
}

\begin{abstract}
Resumo
O objetivo deste artigo é identificar como os gestores da cadeia carne brasileira da carne têm respondido à rápida expansão e intensificação das normas vigentes para a exportação. Esse tema relaciona-se com a reestruturação estratégica de exportadores de carne em suas cadeias de suprimento. Os conceitos que embasam o estudo referem-se ao tema da governança de cadeias globais e às normas alimentares internacionais. São apresentados os resultados de seis estudos de caso, abrangendo exportadores de grande e médio porte que fornecem carne fresca para a União Européia. Os principais resultados descrevem os tipos de governança que estimulam upgrading e transferência de melhores práticas e, conseqüentemente, a completa adequação com as normas. Os resultados contribuem para o entendimento da gestão da cadeia brasileira da carne, e, também, são úteis para outras cadeias de suprimentos que atuam em mercados internacionais. As implicações gerenciais mostram os desafios impostos aos exportadores brasileiros para manter suas vendas para a União Européia, bem como as aplicações das diferentes formas de governança de cadeia para a melhoria da adequação com as normas internacionais e aumento da competitividade.
\end{abstract}

Palavras-chave: normas alimentares; cadeias globais; comércio internacional; estudos de caso.

\begin{abstract}
The purpose of this paper is to identify how Brazilian beef managers have responded to a rapid expansion and intensification of standards for beef exports. This issue relates to how some Brazilian beef exporters are strategically repositioning themselves in the supply chains. The literature of this study reviews global chain governance and international standards. The method uses case studies consisting of six medium and large scale beef exporters who export fresh beef to the European Union. The main findings describe the kinds of governance that stimulate upgrading and transferral of the best practices and, consequently, full compliance with mandatory standards. This study suggests that standards do matter for companies trying to increase international competitiveness. These results contribute an understanding of the Brazilian beef chain, and also of other supply chains coping with demanding and changing international markets. Managerial implications show the challenges facing Brazilian beef exporters in their efforts to sustain exports to the European Union and how they are using chain governance to improve their compliance with international standards and increase competitiveness.
\end{abstract}

Key words: food standards; global chains; international trade; case studies. 


\section{INTRODUCTION}

Food standards are mandatory for international trade. Developing country exporters are penetrating the high value food market and increasing their market share as well as international competitiveness. In order to do so, they have to respond adequately to consumer concerns over quality and safety. This is particularly important to the beef sector, where recently a number of contaminations and outbreaks have negatively affected consumption. There are different standards covering food and food products: international public standards (such as Codex Alimentarius); the importer's public standards, which may vary from country to country, foreign (importing) retailer's standards, domestic public standards and domestic retailer's standards. These standards have a full supply chain coverage in common to avoid risk. Most developing countries consider them as non tariff barriers to international trade. However, others have successfully expanded their exports of high value and value-added food products, complying with both public and private standards.

This paper exemplifies this discussion, demonstrating how some Brazilian beef managers have responded to this rapid expansion and intensification of standards and have reached leadership on beef exports. It illustrates how Brazilian exporters are strategically repositioning themselves in the supply chains, based on the results of case studies of private and public standards within the Brazilian beef chain. The Brazilian beef industry is largely export oriented, with over US\$ 1 billion having been exported between 2001 and 2002. Local companies are the main beef processors, unlike other food sub-sectors that are dominated by transnationals (Farina \& Viegas, 2003; Jank et al., 2001). Brazil is also a big consumer market for beef (35.5 kg annually per capita, according to the United States Department of Agriculture - USDA). These results will contribute to an understanding of the Brazilian beef chain, but also other supply chains coping with demanding and changing international markets. Results will help in the formulation of adequate public policies regarding domestic regulations and to increase overall competitiveness. It also has managerial implications on the compliance with private and public standards.

The paper is structured as follows: Section 2 provides a review of the theoretical framework to be used (chain governance) as well as the literature on food standards. Section 3 briefly details the methodology of this research, while section 4 summarises its findings. Section 5 discusses the results and Section 6 concludes. 


\section{Theoretical Framework}

This section reviews the literature on chain governance and food standards and uses it to create a framework for this study. It takes a developing country perspective to allow the assessment of gains and threats to Brazilian beef chains. Of fundamental importance is the identification of the agent responsible for the setting and monitoring of the standards, particularly when considering a global food chain (Masakure et al., 2004), with the participation of transnational companies.

\section{Global Commodity Chain}

Global chain management is an important and new area of recent research in international studies (Griffiths \& Myers, 2005; Larson, 1992) and focuses on the governance of inter-firm relationships. A global chain consists of multiple business partners across countries, aiming to maximise the overall performance of their transnational companies. However, there is a lack of studies assessing the impact of global chain governance on developing country firms. As an alternative, the Global Commodity Chain Analysis (GCC) approach enables a clearer understanding of the complex issues of globalisation, and the prospects for wider economic growth and poverty reduction in developing countries. It does so by underlining the predominance of 'buyer driven' supply chains, where few leading retailers compete on non-price factors and impose exacting quality and food safety standards on suppliers. To date it has been applied in apparel (Gereffi, 1994, 1999) and recently to commodities (Dolan \& Humphrey, 2000).

Global Commodity Chain (GCC) is a method of analysis focusing on governance structure, power and the institutional framework within global production and the spread of manufacturing in developing countries. Gereffi (1994) differentiates two types of chain configuration and governance structure: producer driven and buyer driven. The first means a chain where large companies (usually transnational) co-ordinate the whole supply chain, characterised by capital and technology intensive industries such as automobiles and computers. Here, the main strategy is to attain economies of scale in manufacturing. Traditional examples of chain governors on producer-driven chains are automobile companies such as Ford and General Motors. Conversely, buyer-driven chains focus on the domination of retail companies and brand-name merchandise. These compete intensively against each other by continuing minor innovations to products and packaging, by the maintenance of strict quality criteria and by price. Traditional examples are UK supermarkets, Nike and Reebok (Gereffi, 1994). These companies are merchandisers that design or market the products that they sell. Gereffi (1994) 
recognises that both systems, the buyer and the producer driven, may be contrasting, but not mutually exclusive. Large companies play the role of the governor, creating and monitoring their own standards. They may be manufacturers detaining technological and production information (producer-driven) or retailers or branded companies concentrating on the possession and translation of market information. Traditionally, the food industry has displayed the characteristics of the producerdriven chain, dominated by big processors (Nestle and Heinz, to name only two). However, the concentration of retailing is challenging the position of large processors. Big retailers are leading the food industry to become more buyer driven, especially due to the success of the own brand strategies. The governor of the chain is the establisher of the standards and should have sufficient size and capacity to monitor the standards, while the supplier should have the capacity to invest to meet the standards. Being a chain governor increases the responsibility of the retailer in the supply chain. Consequently, such supermarkets develop and aim to hold capabilities that can develop competing chains worldwide.

Governance can be provided from within or from without the chain. Kaplinsky (2000) identifies three possible forms: legislative governance, where the basic rules are set that define the conditions for participation in the chain; judicial governance, which means an audit of performance and monitoring for compliance, and executive governance, a more proactive form of governance providing assistance to chain members to meet the conditions. The three categories are summarised in the table below:

\section{Table 1: Examples of Legislative, Judicial and Executive Governance}

\begin{tabular}{|l|l|l|}
\hline Kinds of Governance & $\begin{array}{l}\text { Exercised by parties internal to } \\
\text { chain }\end{array}$ & $\begin{array}{l}\text { Exercised by parties external to } \\
\text { chain }\end{array}$ \\
\hline $\begin{array}{l}\text { Legislative governance } \\
\text { (related to international } \\
\text { standards) }\end{array}$ & $\begin{array}{l}\text { *Setting standards for suppliers in } \\
\text { relation to on-time deliveries, } \\
\text { frequency of deliveries and quality }\end{array}$ & *Chvironmental standards \\
\hline $\begin{array}{l}\text { Judicial governance } \\
\text { (related to public national } \\
\text { standards) }\end{array}$ & $\begin{array}{l}\text { Monitoring the performance of } \\
\text { suppliers in meeting these standards }\end{array}$ & $\begin{array}{l}\text { *Monitoring of labour standards by } \\
\text { NGOs }\end{array}$ \\
\hline $\begin{array}{l}\text { Executive governance } \\
\text { (related } \\
\text { to private standards) }\end{array}$ & $\begin{array}{l}* \text { Supply Chain Management } \\
\text { assisting suppliers to meet standards } \\
\text { *Producer associations assisting } \\
\text { members to meet these standards }\end{array}$ & $\begin{array}{l}\text { *Specialised service providers } \\
\text { *Government industrial } \\
\text { support policy }\end{array}$ \\
\hline
\end{tabular}

Source: adapted from Kaplinsky, 2000.

The table above describes the different roles played by different agents in the establishment and/or monitoring of standards. It is fundamental to identify who is 
responsible for these tasks to understand chain dynamics. The governor can be considered the chain strategist. He is the one who determines the future of the chain. From the table above, obvious links can be seen between governance and standards. The international organisations responsible for the establishment of standards (such as World Trade Organisation) would exemplify legislative governance. Judicial governance is the enforcement of standards made by national governments (for example, MAPA - the Brazilian Ministry of Agriculture). Finally, executive governance relies on private standards. Governance can therefore be exercised in different ways and through different agents throughout the length of the entire food supply chain, depending on the standards present. Supply chains may have parts of the process co-ordinated and controlled, while others are regulated by spot market transactions. Governance may transmit not only technical information (such as technical standards) but also market information which helps companies to forecast consumer trends and identify niche markets. This paper proposes that the form of chain governance may influence access to the international market and international competitiveness of an exporting company.

\section{Food Standards}

Standards are mandatory for international trade. Food standards are "rules of measurement established by regulation or authority" (Reardon et al., 2001) and are enforced by governments, food companies and retailers. Their aim is to assure the confidence of consumers in the food systems (from farm to table), but also increase the information available to the final consumer, enabling them to make informed decisions concerning the food they purchase. There are three different kinds of standards: namely process, product or information (Caswell, 2003), but most regulations use a combination of the three to regulate food processing and marketing. Briefly stated, process standards specify how the product should be produced; a product standard requires that the final product should have specific features; and last, information standards are concerned with labelling and other communications that go with the product.

For the food processor and retailers, standards are important in differentiating and communicating product quality and safety to the consumers as well as being a competitive strategy. This has become a particularly important issue for developing countries, where the compliance with standards may be difficult, yet mandatory for trade (see Donovan et al., 2001; Henson \& Loader, 2001; Farina \& Reardon, 2000). Governments, international organisations and private companies try to ensure safety and quality by imposing compulsory minimum standards for a product and banning the sale of any item that does not comply with certain minimum criteria. 
The literature on food standards has focused on two analytical approaches (Jaffe \& Henson, 2004). The first and more dominant approach focuses on mandatory standards and international standards ruled by the World Trade Organisation (WTO), broadening the standards of developed countries (United States, Japan and European Union). Most studies consider standards as barriers, highlighting the technical and managerial difficulties that developing countries face in compliance. The second approach emphasises the opportunities brought by standards and how developing countries can use those opportunities to their competitive advantage. This is provided especially by private standards such as industry codes of practice and quality assurance schemes.

Research shows the need to improve Brazilian beef chain co-ordination as a key point (Aguiar \& Lago da Silva, 2002; Ferreira et al., 2001; Michels et al., 2001; Silva \& Batalha, 2000; Zylberstajn \& Machado Filho, 2003). One of these studies (Aguiar \& Lago da Silva, 2002) assesses the competitiveness of beef retail in Brazil. Results show that one of the issues that affects competitiveness in negative terms, according to the point of view of the retailer, is related to the inappropriate co-ordination of the chain, not using practices of supply chain management. This study suggests that to overcome the problems faced by retailers, they do not depend only on these, but on related firms and government. But the authors suggest that, due to its high degree of concentration, the retail link should be in charge of organising the beef chain in the domestic market. To a certain extent, this papers tests this suggestion on the context of international trade and the impact of standards, expanding the concept from co-ordination to governance.

\section{Method}

Case study is a popular method in applied social sciences (Sociology, Management and Business) and, recently, agricultural economists have been applying these methods (Sterns et al., 1998; Westgren \& Zering, 1998), especially those researching the business management of food companies. Authors believe that agribusiness researchers are in a privileged position to be closer to industry than researchers of strategy behaviour in other industries. Westgren and Zering (1998, p. 419) affirm that when doing research, it is first important to define the event. When concerned with the event of price and income elasticities (what happened?), researchers use an econometric study of demand system to measure this. On the other hand, when examining the changes to organizational forms in evolving food markets (what is happening?), one may focus on alliances and 
contracts. They argue that case studies can illustrate the range of organizational forms and strategies used in an industry, without attempting to calculate their incidence.

Here, cases are analysed sequentially, treating each one independently of the others, respecting its uniqueness so that the particularities may maximise the theoretical insight. As the analysis proceeds, the guiding theoretical notions are assessed in the light of the findings. Data can contradict or reveal previously unseen inadequacies in the theoretical notions guiding the research, providing a basis for reassessment or rejection. The data can also confirm the theory or may force us to create new hypotheses, adding detail to the theory and more fully specifying it.

A multiple case-design analysing multiple units brings the advantage of being able to alternate the unit of analysis and avoid doubts about generalisation. It provides many differing observations of the phenomenon, each slightly different according to the context (Miles \& Huberman, 1994). The objective of multiple case research is to see processes and outcomes across many cases, to understand how they are qualified by local conditions, and thereby to develop more sophisticated descriptions and more powerful explanations.

This research involved three steps. The first step was the identification of industry participants and existing vertical or horizontal relationships using experts and secondary data to build a profile of the industry structure. Initially, the researcher conducted a rapid appraisal with an extensive gathering of secondary data (newspapers, technical magazines, academic studies) and nineteen semi-structured interviews with key informants (associations, academics and members of the Ministry of Agriculture). The objective was to learn more about the Brazilian beef chain.

The second step (carried out between 2001 and 2002) was to identify and describe existing standards within selected export companies. Six exporters were selected following rapid appraisal because of their diversity and increasing export market share. Four European importers were also interviewed. The cases studies were conducted analysing documentation through focused interviews and direct observation (site visits). The documentation analysed was secondary data (such as codes of practice, journals, newspapers and technical magazines) and promotional brochures provided by the companies visited.

The focused interviews took about two hours following a set of questions. When permitted, the interviews were recorded on tape. The sessions focused particularly on the following issues: activities carried out by the company; interactions with other links (suppliers, customers) and to what degree; input and output features; 
how this information is collected; how prices are determined; participation in schemes designed to control FMD (foot and mouth disease); implement of HACCP (Hazard Analysis and Critical Control Point); establishment of certification and traceability; and brand establishment, amongst others.

The last step consisted of the analysis of the case studies. The reliability of the data was increased through the development of clearly conceptualised constructs and the use of multiple indicators. The in-depth interviews were conducted and analysed by the author, and then discussed with the key persons. To check for validity, after the case studies, a previous analysis was exposed to the key people and to some of the case study interviewees to confirm the information gathered. The use of multiple sources (in-depth interviews, annual reports, secondary data and direct observation) also aimed to improve the construct validity. Any claim was supported with multiple evidence when possible (Miles \& Huberman, 1994; Yin, 1994).

\section{Brazilian Beef Chain}

This section begins by presenting and discussing the case studies. Following this, similar patterns of export companies are discussed. Then, a short analysis connects cases to the theoretical framework.

\section{Export Standards}

The cases consist of six medium and large scale beef exporters which export fresh beef to the EU. They can be characterised as family businesses located in Rio Grande do Sul and Mato Grosso do Sul They export an average of 40 to $60 \%$ of their total sales. The importers interviewed were four European Union buyers. Given that the individuals interviewed were not the decision makers, they preferred to focus on technical issues rather than strategy.

Regarding standards, all beef exported to the EU must originate from animals that have never been treated with growth hormones. Shipments must be accompanied by a health certificate as evidence of this. Both the health certificate and the certificate of origin must be obtained from an inspector present in the exporting establishment. The competent authorities in the EU countries issue import licenses and communicate to the European Commission the quantity of license applications on a monthly basis. Brazil has a small quota of 5 thousand tons/year of Hilton quota (standards for young steers imposed by the EU), paying a tax fee of $26 \%$ as opposed to the $130 \%$ they would pay if they were not included 
in this quota. Currently, several importers have been asking for Hilton standards, even if the sales transaction is not included in the import quota.

The importers interviewed had some experience with Brazilian beef purchases. All of them had been purchasing Brazilian beef for at least two years. Regarding compliance with standards, these importers pointed out some common mistakes among Brazilian exporters such as the lack of identification labels of the product on delivery, incorrect information on the label, or a wrong label, and errors in the sanitary certificate. These problems are related to information standards.

The EU importers rely on the Brazilian Ministry of Agriculture (MAPA) inspection system to control safety, although they inspect the processing plants personally two to four times per year. Table 2 presents the main controls in export prescribed by international organisms and enforced by MAPA. All beef exporters have to fully comply with them.

\section{Table 2: Export-driven Standards}

\begin{tabular}{|l|l|}
\hline Attributes & Public Standards \\
\hline Beef Production & The use of any source of animal protein when feeding ruminants is forbidden. \\
\hline Animal Welfare & none \\
\hline Traceability & $\begin{array}{l}\text { The Brazilian System of Identification and Certification of Bovine Origin } \\
\text { (SISBOV) is an identification system for the registration of bovine livestock, } \\
\text { involving the individual identification of the animal on farms and processing plants, } \\
\text { an animal passport and the creation of a data base. MAPA recognises certifying } \\
\text { bodies as responsible for registration, data transmission and inspection. }\end{array}$ \\
\hline Food Safety & $\begin{array}{l}\text { Ante mortem (before slaughter) inspection to detect any diseases. } \\
\text { Post-mortem tests after the slaughter, checking: the animal's organs (foot, head and } \\
\text { tongue, kidney, among others) and age (teeth). After these tests, the carcass receives } \\
\text { a stamp confirming the inspection, then it is cleaned and maintained in cold storage. }\end{array}$ \\
\hline Pathogens/toxins & $\begin{array}{l}\text { Beef to be commercialised should be maintained in the chilled room at a } \\
\text { temperature of around } 4^{\circ} \mathrm{C} \text {. Delivery should be made below the temperature of } 7^{\circ} \mathrm{C} .\end{array}$ \\
\hline Carcass specification & Brazil has not yet implemented a classification of carcasses according to quality. \\
\hline Target animal & All animals under federal inspection intended for export. \\
\hline
\end{tabular}

Source: interviews.

The beef exporters are under constant inspection from the MAPA and this inspection system is considered equivalent between Brazil and the EU. Importers believe that the Brazilian regulation has been modernised and enforce the same issues as the EU regulation.

\section{HACCP}

Interviews showed that particularly relevant to the beef export are the implementation of HACCP (Hazard Analysis and Critical Control Point). Usually, HACCP is a process standard that consists of an internal team identifying critical 
control points throughout the process. Critical points in beef processing generally cover areas such as receiving raw materials, packaging materials, cleaning chemicals, process equipment, and temperature control of products during processing, chilling and freezing. Investment in microbiological testing is also undertaken. The beef processor must prove that control schemes are efficient and applied daily. Interviewees pointed out that HACCP, in the first instance, may increase costs to beef processors, especially in an industry with low margins such as beef processing, but costs vary with company size. Processors calculate that they spend $25 \%$ more on management time and machinery needed for compliance than those processors only supplying the domestic market. For large processors however, HACCP is a one-off expenditure and the mainly large scale production easily justifies an investment of this type. Caswell (2003) recognises that HACCP does not prescribe specific actions to be taken and the company is free to choose its own methods for hazard control. Each country can also enforce HACCP in different ways. The EU has mandated HACCP for all levels of the supply chain, while the US does so only for some specific chains (beef being one of them). For a processor in a developing country, the benefits of adopting HACCP come in the form of access to export markets, cost savings and safety improvements.

\section{Traceability}

Traceability is the "ability to maintain a credible custody of identification for animals or animal products through various steps within the food chain from the farm to the retailer" (CODEX, 2002). Before beef trade can occur, importing countries must be satisfied that the animal health status of the home country will be appropriately protected. However, traceability systems operating in the exporting and importing countries may differ. The EU, for example, has directives $1760 / 2000(17 / 07 / 2000)$ and 1825/2000 (25/08/2000) establishing a system for the identification and registration of bovine animals and the labelling of beef and beef products. The identification system to register bovines should consist of the individual identification of the animal, creation of a data base with cattle information, animal passports (for any animal movement) and individual registration of the animal. The EU requires that all exporting countries to the EU should comply with the same standards adopted by the block. The exporting country has the responsibility to objectively demonstrate how the proposed measure can guarantee safety. Interviews showed that this is the main constraint to full compliance with public standards. Exporters face the difficulty of obtaining information pertaining to the origin of the cattle because of the rejection by producers to adhere to traceability schemes. To sustain exports, the interviewees said that they vertically integrate (owning farms) or pay premium price to selected suppliers. 


\section{Quality Assurance Schemes}

Quality assurance schemes are relatively new in Brazil. They have been implemented by transnational groups with their own brand products (such as Carrefour) or transnational food companies which select and upgrade suppliers (i.e. Nestle as described by Reardon \& Farina, 2001). A quality assurance scheme (QAS) is an organizational structure, procedures, processes and resources needed to implement quality assurance. This study identified only one case concerning beef. This QAS is led by a European retailer which provides an international certification allowing beef suppliers to supply locally and to the EU. These beef suppliers have to follow a strict code of practice and are inspected by the retailer or private vets. These standards are summarised in Table 3.

\section{Table 3: Examples of Standards enforced by European Retailers}

\begin{tabular}{|l|l|}
\hline Attributes & Private Standards \\
\hline Beef Production & $\begin{array}{l}\text { The supermarket only accepts extensive production. It sets standards and inspects the } \\
\text { following issues: water management, labour, facilities, fences, tools, weight, and food } \\
\text { and transport conditions. Ecologically friendly production (erosion control, } \\
\text { maintenance of green areas and wild life and pasture rotation) and concern over } \\
\text { animal welfare (regarding transport conditions, medicines, handling, among others). } \\
\text { Producer must keep records. }\end{array}$ \\
\hline Target Animal & $\begin{array}{l}\text { Animals with four teeth (average } 30 \text { months) having from } 3 \text { to 10 mm fat cover, half } \\
\text { blood Hereford or Bradford; } \\
\text { Linear conformation, sub convexes and convexes } \\
\text { Female weight over 180 kg carcass } \\
\text { Male weight over 200 kg carcass }\end{array}$ \\
\hline Traceability & $\begin{array}{l}\text { Beef producers must have implemented a traceability system according to the } \\
\text { SISBOV (MAPA's regulation to export companies). }\end{array}$ \\
\hline Beef Processor & $\begin{array}{l}\text { Special attention to carcass management regarding meat tenderness (maturation and } \\
\text { cooling temperature according to PH down curve). Processor must keep records. }\end{array}$ \\
\hline Food Safety & $\begin{array}{l}\text { Based on a strict traceability system (animal's origin and feeding). Vet certifies the } \\
\text { breed and checks the animal's health before the slaughter. Then, the slaughter process } \\
\text { is inspected. }\end{array}$ \\
\hline Sensory & $\begin{array}{l}\text { The British blood breed assures product tenderness and taste. } \\
\text { with the international standards and allows it to be sold in all shops of this } \\
\text { international chain. }\end{array}$ \\
\hline Branding/labelling \\
\hline
\end{tabular}

Source: interviews.

The EU retailer and the Brazilian beef exporter referred to the existence of detailed contracts, but they did not have permission to show the documents to the researcher. However, they mentioned that there are safeguards and sanctions for all the agents involved. The own-brand standards are explained in a code of practice that outlines all the best practices in beef production and processing. The standards are the same as those used in this supermarket's home country, where concerns over mad cow disease and dioxins are high and affect consumer trust in 
beef consumption. Standards are varied and encompass process and product issues. The supermarket controls the whole production/process systems, and imposes sanctions on those not complying with the stricter standards.

The supermarket transfers the knowledge and practices from the home country. Good agricultural practices including animal welfare and environmental standards, relatively new to the Brazilian practices, are enforced. The supermarket provides training and assistance for good production and management practices, thereby upgrading their production systems. For the processors, compliance with these quality assurance scheme standards acts to improve their production, as well as quality, and increase their competitiveness. Although this initiative is recent, all the members interviewed appear satisfied and optimistic with the results achieved and the potential for future growth. The general satisfaction increases the level of institutional trust, relying on the supermarket's reputation. As a result of this relationship, the exporter is becoming better qualified to supply branches in the EU. What is new in this case is that the own-brand scheme is advantageous to the suppliers involved, because they have an active participation in chain decisions.

\section{Discussion}

This section uses the findings to discuss the role and implications of public and private standards for companies already participating in, and those considering entering, international markets. In export chains, the majority of companies interviewed use public standards as the basis for their compliance. Brazilian regulations are constantly updated and include issues based on EU directives and CODEX related to the export driven chains.

The evidence from rapid appraisal suggests export chains are characterised as being buyer driven with international wholesalers and retailers dictating "the rules of the game" (Gereffi, 1994). The governor is the link determining prices and standards, the positioning in the market, the distribution of functions between the components of the chain and inclusions or exclusions of the export market. In all cases studied, the buyers (wholesalers/retailers) are in charge of these issues.

In beef export, enforcement and monitoring of standards by MAPA is limited because there is little inspection and no sanctions for non-compliance by importers. Regarding food standards, export companies comply with the basic forms, which are based on public standards as set out by the Brazilian government. Importers count on legislative governance (Kaplinsky, 2000), which is characterised by the setting of standards for transaction terms. Importers assume that the Brazilian public 
sector is responsible for monitoring the full processing while the importer only randomly inspects the final product. There is no knowledge transfer or assistance to the supplier concerning public standards. However, importers are concerned when beef is imported using their own brand and exercise executive governance.

Governance draws attention to companies increasing the degree of chain coordination. This is crucial for the use of increasing product differentiation as marketing strategy by large companies. Governance also helps producers to meet standards. In this study, one case study presented an EU retailer that developed its own standards, including quality, food safety and environmental issues. These standards are based on international public and private (from their own home companies or benchmarking) standards and transfer of practices developed in their home country. It provides varying levels of technical assistance for producers and processors.

This retailer tends to store information about the end consumer to set beef standards. The transmission of these standards can be advantageous to the processor in maintaining an important and large-scale marketing channel. Coordination using co-operation aims to promote the supermarket's own brand and, consequently, its reputation. It is interesting to note that when the same processor supplies a customer supermarket with the processors' own-brand, these transactions happen through the spot market. This demonstrates that advantages, such as preferential treatment, are not transferable for other transactions between these agents. They compete in the same way with other suppliers who do not have such a close relationship with the supermarket purchasers.

The importance of compliance with public standards was experienced in 2001 , when beef processors suffered export bans due to an outbreak of foot and mouth disease in the region where they are located. The outbreak contaminated the livestock of small beef producers who supplied local slaughterhouses. However, the ban showed the importance of integration in the chain and how the concern of one link can affect the whole. Since this experience, these processors are making efforts to develop long-term partnerships.

Export food standards are split into two types: process monitoring and product compliance. Traceability emerges as the challenging process standard. When the MAPA enforced a traceability scheme in June 2001, a quality manager anticipated that beef processors would pay a market price for traceable cattle and a below market price on non-traceable cattle. This comment highlights how processors still consider compliance with standards as a top-down process. For example, companies (private standards) or countries (public standards) enforce the compliance of a certain standard, and local companies have to comply in full. Consequently, Brazilian beef processors demand traceable livestock and farmers 
need to cover this requirement. This leads to an adaptation problem as producers do receive neither information nor an incentive. Recently, several beef exporters have not been able to slaughter and export because there are no traceable cattle.

Importers do not provide any kind of training or assistance and learning by doing has high costs. For example, beef processors themselves contracted international experts to learn how to comply with these standards according to different national and international legislation. Nevertheless, the improvements made at the processing plant and farms owned by the processor are also useful for the domestic market supply, although there is no premium price for safer beef internally. The main motivation for the implementation of a traceability scheme on the processor's own farms is that the managers felt that traceability could not be assured when buying livestock at auctions. The availability of suppliers within the scheme is low. However, processors are likely to establish alliances with those producers who comply.

All active exporters invested in HACCP in the late 1990s. The largest companies are willing to implement new quality control systems because they are a one-off expenditure and their large scale production justifies such an investment. One beef processor admitted that they will do whatever the importer wishes to keep them happy, unless it means losing money. In his experience, HACCP is an important and efficient tool for assuring some aspects of food safety. It is also seen as a pro-active system that includes several international regulations.

International standards are restructuring relations and upstream functions as well as the behaviour of processors and producers. This has changed the power dynamics in the chains, with more power now vested in buyers who relegate functions upstream.

\section{Conclusions}

Exporting entails dynamic learning curve effects and upgrading capabilities (Gereffi, 1999). The imposition of international standards is resulting in organisational change, business approaches and behaviour, and has raised production standards which have positive spill over effects in local markets (Farina \& Reardon, 2000). There is a move from competition towards co-operation, albeit a slow move. The application of standards entails the exercise and potential abuse of power by chain leaders. Regarding the use of GCC, it is consistent in analysing the emergence of a new global manufacturing system that goes beyond international trade to encompass coordinated but internationally dispersed production of beef (Raikes et al., 2000) The 
study highlights power, governance and the institutional framework. The market and non-market power (Dolan \& Humphrey, 2000; Gereffi, 1994, 1999) involves the ability to affect market price outsource lower value-added activities and to retain or incorporate those with higher valued- added. However, the exploratory results of this study point out that power can also be paradoxical (Fearne, 1998, p. 228) in that, over time, buyers become more reliant on their suppliers who become the providers of brand integrity and have the capacity to innovate and add value. The institutional environment analysis shows that key agents within and outside the chain (government, certification bodies, retailer) can enforce contractual and performance obligations upon members upstream even against their will. The analysis of governance gives credence to the role of buyers in facilitating compliance with standards. However, this can be done through different forms of governance. A previous study of the Brazilian poultry chain relates the executive governance exercised by industry (producer-driven) as the main driver to international competitiveness (Nogueira, 2004). Another recent study identified the exporter as the executive governor of small and medium sized fresh producers (Henson et al., 2005). However, this study is aligned with Dolan et al. (2000), who identified the role of retailer as more agile in developing and enforcing strict standards based on EU regulation and still not adopted by other countries. The transfer of these standards to firms located in developing countries is faster and more comprehensive, providing incentives for compliance. The other two forms of governance, legislative and judicial, seem less likely to sustain international competitiveness on sophisticated markets. Regulation is an important driver to organizational change though executive governance and may be more efficient and less time consuming for developing countries producers.

This study agrees with previous studies that standards do matter for companies trying to increase their international competitiveness (Jaffe \& Henson, 2004; Reardon \& Farina, 2001). From a policy perspective, the study shows the challenges facing Brazilian beef exporters in their efforts to sustain exports to the EU. These difficulties are partially related to the need for the exporters to comply with the increasingly complex and demanding food safety and food quality standards that have become mandatory in markets. The findings show that while processors were managing to comply with product standards, compliance with process standards remained a problem for many beef processors. This suggests that processors were lacking the vital information regarding the nature and demands of these standards and the role of traceability and certification, as well as how product differentiation can yield a significant price and add market value to the processors. There is a need for the public and private sectors to work together in order to identify efficient and effective ways of enhancing capacity for compliance with standards. Private companies are already replacing the public sector on quality monitoring (Reardon \& Farina, 2001). This should be promoted more widely 
in Brazil to enhance compliance with standards and supply chain integration. The creation of external agents facilitating the information flow to producers or, even better, to whole chains, would be a great achievement.

The second implication concerns the need for more efficient inspection and control of food safety and quality regulation in the domestic market. The Brazilian regulations are updated and aligned to the recommendations of international organizations. However, a gap still remains between practices adopted for the export market and practices adopted locally. There are several factors that account for this. First, there is the lack of human capital and technology. Second, the market dictates no urgent need for safer and higher quality beef because consumers are not willing to pay. Third, there is not enough advertising/publicity to convince consumers of the benefits of safer, better quality beef. In this case, policies should take into account the success of supermarket strategies in offering differentiated products. Government should also increase the capacity of small firms and farms to meet the requirements implied by these private standards. This will prevent them from being excluded from the market.

From a practical perspective, the results also have important implications for managers of the beef chains in particular and other chains in general. First, it was shown that chain governance as exercised by the supermarket is becoming a source of competitive advantage. Second, as shown by the literature in other chains (Hayes \& Lence, 2002; Raynaud et al., 2002) exporters' own-brands have grown significantly in recent years and have the capacity to encourage on greater competitiveness. This supply can be controlled by limiting membership of the producer group to a relatively small number of high-quality producers. Third, developed country consumers have been driving the changes in process and product standards through their insistence on safer and better quality food and traceability. Consumer pressures are also changing the structure, operations and functions of agents in supply chains, effectively the 'rules of the game'. Processors must be able to monitor constantly and follow trends in international markets if they are to remain competitive.

Further research is suggested on the increasing formation of global chains, where the presence of international players is quickly changing transaction features. These relationships tend to be hierarchical but are changing to become increasingly based on trust. The main challenge that the GCC poses is how to transfer this knowledge of stricter standards to alternative markets or increase bargaining power facing the global buyer. Another question is whether the "buyer-driven" remains over time or if Brazilian exporters can move up to a "producer-driven" chain and how this change can be achieved.

Artigo recebido em 20.07.2005. Aprovado em 23.09.2005. 


\section{References}

Aguiar, D. R. D., \&

Lago, A. S., da (2002, Spring).

Changes in beef consumption and retailing competitiveness in Brazil: a rapid appraisal. Agribusiness, 18(2), 145-161.

Caswell, J. A. (2003).

Food safety. In L. J. Unnevehr (Ed.). Food safety in food security and food trade. Washington: International Food Policy Research Institute.

Codex Alimentarius Commission (2002). Retrieved 15 junho, 2002, from http:// www.codexalimentarius.net/web/ index_en.jsp

Dolan, C. S., \&

Humphrey, J. (2000, December).

Governance and trade in fresh vegetables: the impact of UK supermarkets on the African horticulture industry. Journal of Development Studies, 37(2), 147-176.

Donovan, J. A.,

Caswell, J. A., \&

Salay, E. (2001, Spring/Summer).

The effect of stricter foreign regulations on food safety levels in developing countries: a study of Brazil. Review of Agricultural Economics, 23(1), 163-175.

Farina, E. M. M. Q., \&

Reardon, T. (2000, December).

Agrifood grades and standards in the extended Mercosur: their role in the changing agrifood system. American Journal of Agricultural Economic, 82(5), 1170-1176.
Farina, E. M. M. Q., \&

Viegas, C.A. S. (2003).

Multinational firms in the brazilian food industry. Proceedings of the World Food and Agribusiness Forum, Cancun, Mexico, 13.

Fearne, A. (1998, December).

The evolution of partnerships in the meat supply chain: insights from the British Beef Industry. Supply Chain Management, 3(4), 214-231.

Ferreira, G. C.,

Padula, A. D., \&

Silveira, C. E. (2001).

Definition and diffusion of productive patterns in supply chain: a study of the beef meat in Rio Grande do Sul, Brazil. Proceedings of the International Conference on Management Technology, Lousane, 10.

Gereffi, G. (1994).

Organisation of buyer-driven Global Commodity Chains: How U.S retailers shape overseas production networks. In G. Gereffi \& M. Korzeniewicz (Eds.) Commodity Chains and Global Capitalism. Westport, Conn.: Greenwood Press.

Gereffi, G. (1999, June).

International trade and industrial upgrading in the apparel commodity chain. Journal of International Economics, 48(1), 37-70. 
Griffiths, D. A., \&

Myers, M. B. (2005, May).

The performance implications of strategic fit of relational norm governance strategies in global supply chain relationships. Journal of International Business Studies, 36(3), 254-269.

Hayes, D. J., \&

Lence, S. H. (2002).

A new brand of agriculture: farmerowned brands reward innovation. Choices, 17(4), 6-10.

Henson, S., \&

Loader, R. (2001, January).

Barriers to agricultural exports from developing countries: the role of sanitary and phytosanitary requirements. World Development, 29(1), 85-102.

Henson, S., \&

Wilson, J. S. (2005).

The WTO and technical barriers to trade. London: Edward Elgar Pub. Co.

Jaffee, S., \&

Henson, S. (2004, June).

Standards and agro-food exports from developing countries: rebalancing the debate. Policy research [Working Paper], 3348.

Jank, M. S.,

Leme, M. F. P.,

Nassar, A. M., \&

Faveret, P. (2001, April).

Concentration and internationalization of brazilian agribusiness exporters. International Food And Agribusiness Management Review, 2(3-4), 359-374.
Kaplinsky, R. (2000).

Spreading the gains from Globalisation: what can be learned from value chain analysis. IDS [Working Paper] (p. 37). The University of Sussex, 110.

Larson, A. (1992, March).

Networks dyads in entrepreneurial settings: a study of governance of exchange relationships. Administrative Science Quarterly, (37), pp. 76-104.

Masakure, O.,

Vieira, L. M.,

Traill, W. B., \&

Henson, S. (2004).

Global food chain: what is the alternative for developing countries? In H. J. Bremmers, S. W. F. Omta, J. H. Trienekens, \& E. F. M. Wub (Eds). Dynamics in chains and networks. Wageningen: Wageningen Academic Publishers.

Michels, I.,

Sproesser, R. L., \&

Mendonca, C. J. (2001).

Cadeia produtiva da carne bovina de Mato Grosso do Sul. Campo Grande, Editora Oeste.

Miles, M. B., \&

Huberman, A. M. (1994).

Qualitative data analysis (2nd ed.). London: Sage Publications.

Nogueira, A. C. L. (2004).

Estruturas de governança na avicultura paulista. Anais do Encontro Nacional dos Programas de Pós-Graduação em Administração, Curitiba, PR, 28. 
Raikes, $\mathrm{P}$,

Jensen, M. F., \&

Ponte, S. (2000, August).

Global commodity chain analysis and the french filiere approach: comparison and critique. Economy and Society, 29(3), 390-417

Raynaud E.,

Valceschini, E., \&

Sauvee, L. (2002).

Organizational forms and quality strategies in the european agrofood sectors: general synthesis (Rapport pour la commission européenne, project FAIR PL 98-4404).

Reardon, T.,

Codron, J. M.,

Busch, L.,

Bingen, J., \&

Harris, C. (2001, April).

Global changes in agrifood grades and standards: agribusiness strategic responses in developing countries. International Food and Agribusiness Management Review, 2(3-4), 421-435.

Reardon, T., \&

Farina, E. M. M. Q. (2001, December).

The rise of private food quality and safety standards: illustrations from Brazil. International Food and
Agribusiness Management Review, 4(4), 413-421.

Silva, C. A. B., \&

Batalha, M. O. (Eds.). (2000).

Estudo sobre a eficiência econômica e competitividade da cadeia agroindustrial da pecuária de corte no Brasil. Brasília: IEL/CNI.

Sterns, J. A.,

Schweikhardt, D. B., \&

Peterson, C. H. (1998, September).

Using case studies as an approach for conducting agribusiness research. International Food and Agribusiness Management Review, 1(3), 311-327.

Westgren, R., \&

Zering, K. (1998, September/October).

Case Study Research for Firm and Market Research. Agribusiness, 14(5), 415-423.

Yin, R. K. (1994).

Case Study Research. London: Sage publications.

Zylbersztajn, D., \&

Machado Filho, C. P. (2003, April).

Competitiveness of meat agri-food chain in Brazil. Supply Chain Management, 8(2), 155-165. 